\title{
House Price Cycles - the Case of Poland
}

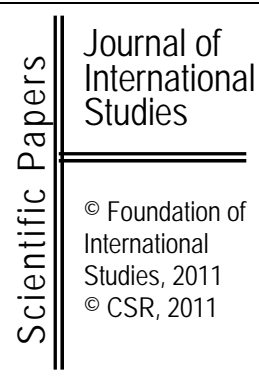

PhD Radosław Trojanek

Department of Investment and Real Estate

Faculty of Management

Poznań University of Economics

r.trojanek@ue.poznan.pl

\begin{abstract}
The main aim of the paper was to identify changes on the secondary housing market in the years 1996-2011 in selected cities in Poland (Gdansk, Gdynia, Lodz, Poznan and Wroclaw). The subject scope results from the aim of the paper and includes price fluctuations on the secondary housing market, involving both property rights and cooperative property rights for private accommodation. In this research only dwellings located in multifamily buildings are analyzed.
\end{abstract}

Submitted: August, 2011

1st revision: September, 2011 Accepted: October, 2011

Keywords: dwelling prices, estate market, Poland.

JEL classification: E32, R33, P2.

\section{Introduction}

Each market, same as the whole economy, is subject to business cycles. This rule can be applied also to real estate market (Gawron, 2006, p.69). This paper presents three main topics: idea of real estate cycles, survey of residential price cycles in chosen OECD countries and an analysis of dwelling's price cycles in selected cities in Poland in the period 1996 - III Q. 2011.

\section{Idea of real estate cycles}

In time series of variables describing real estate market it's possible to find a trend, as well as seasonal, accidental and cyclic fluctuations. These variables are demand, supply or prices on real estate market ${ }^{1}$. With reference to prices on real estate market we can say about a trend (in most cases these prices are of positive trend, except for Germany and Switzerland where in 1975-2005 real market prices were of decreasing trend.), seasonal fluctuations (an increase of transactions number during summer holidays), accidental fluctuations (decrease of flats prices in flooded areas in Wrocław in 1997) and cyclic fluctuations resulted from economic factors having an influence on behaviour of this market participants.

In foreign real estate market literature we can find various methods of such trends definitions. These definitions mostly refer directly to terms of business cycles in the economy (Key, Macgregor, Nanthakumaran, Zarkesh, 1994, p.9).

\footnotetext{
${ }^{1}$ On account of difficulties to assessthe value of demand or supply, prices on real estate market are taken into consideration in most researches.
} 
Similar definition was proposed by A. Baum (Baum, 2001), who describes real estate business cycle as a tendency of demand, supply, prices and rates of return on property to fluctuations around their long-term trends or average values.

The course of economic fluctuations on real estate market can vary depending on specific segments of this market. These fluctuations are often of national range conditioned by changing economic situation of the country. Taking into account a specific character of property - immobility - economic changes on real estate market are, first of all, of regional and local range. It means that even if the whole economy growths, one region or town can go through stagnation and vice versa. Local real estate market can develop even if the whole economy decreases.

As for the source of origin economic fluctuations on real estate market can be divided into (Dehesh, 1997):

- exogenous economic fluctuations conditioned by external factors such as, for example, changing of percentage rates or changing of income level;

- endogenous economic fluctuations conditioned by internal factors such as delays in reactions of supply to market changes.

Real estate cycles are partly due to imperfection of this market. Delays can be probably the most important factors. Generally, the following delays are singled out:

- delay being a result of price mechanism. Unexpected growth of demand meets a specific supply that is constant in short period of time. Market reaction to achieve short-term balance directs to price adjustment.

- decision-making delay. It is necessary to take into consideration a number of conditions (legal, technical, economical) to prepare and to select a developer's project. Within the process of taking an investment decisions various factors of mutual connections should be taken into account and that makes the whole decision making process more complicated and difficult.

- constructional delay. At the moment when investment decision is definitely made, the project has to be approved and the contract with Construction Company has to be signed.

Medium-term external influences to real estate cycles are strictly connected with an economic growth of the country or local market. They consist of changes of main economic factors such as inflation, percentage rates, GDP. Long-term influences are not of a sudden shock character, but are manifested in form of structural change. Examples of structural changes can be (Rottke, Wernecke, 2003):

- political shock (establishing of the European Union),

- economic change of economies' structures (globalization),

- change in surface-time dimension (new communication technologies),

- growing ecological consciousness (new forms of spatial planning).

Cyclic development of residential markets creates some economic and political implications. These cycles are considered not to be eliminated, but knowledge of reasons and results of these cycles can limit some of their indications (Kucharska-Stasiak, 2006). Researches regarding fluctuations on real estate market can be divided into researches on national, regional and local markets.

\section{Review of price cycles on real estate market in chosen OECD countries in 1970-2004}

In a straight majority of OECD countries real property prices were steadily increasing as from the middle of 1990. Graphs 1,2, 3 and 4 present development of indexes of real property prices of eighteen OECD countries in 1975-2004. These selected countries had been classified due to level of an increase or decrease of property prices after 1995 (Girouard, 
Kennedy, Noord, Andre, 2006). The first group consists of countries in which real growth of property prices amounted to more than 100 per cent. The second group consists of countries in which real growth of property prices amounted to 60-100 per cent. The third group consists of countries in which this growth amounted to 60 per cent. The fourth group consists of countries in which real property prices decreased.

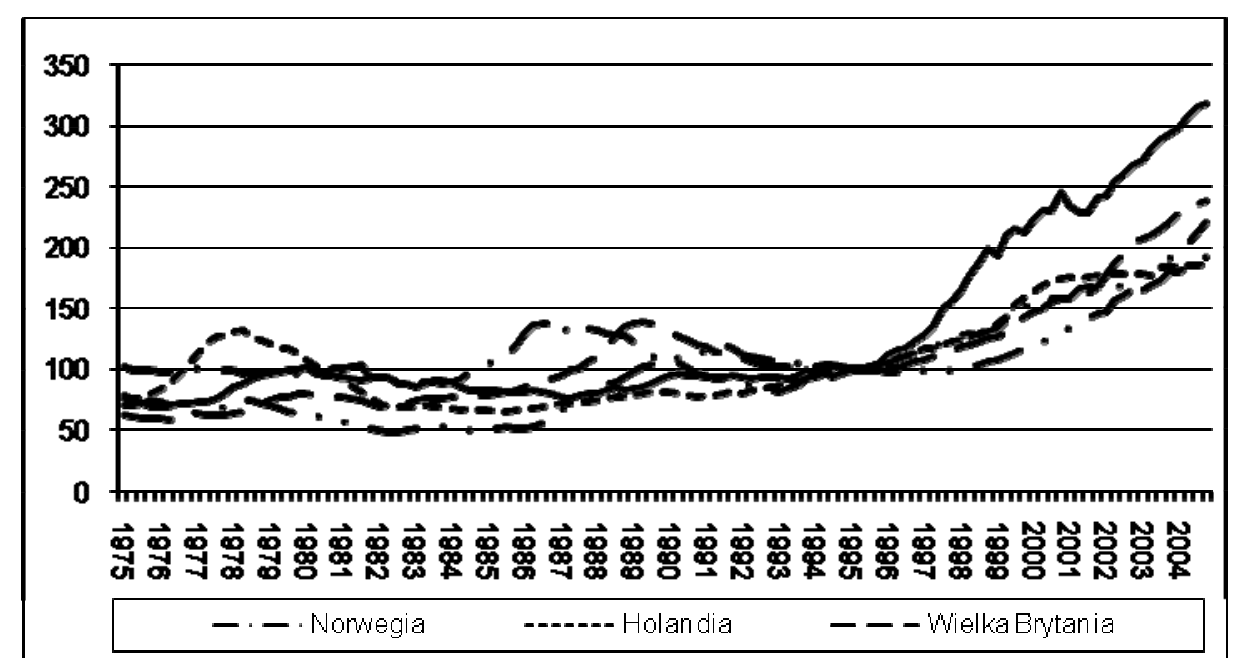

Graph 1. Real house price indexes in Spain, the Netherlands, Ireland, Norway and Great Britain in 1975-2004 ( I Q. $1995=100$ )

Source: N. Girouard, M. Kennedy, P. van den Noord, Ch. André, Recent House Price Developments: the Role of Fundamentals, Economics Department Working Papers No. 475, 2006 , p. 5.

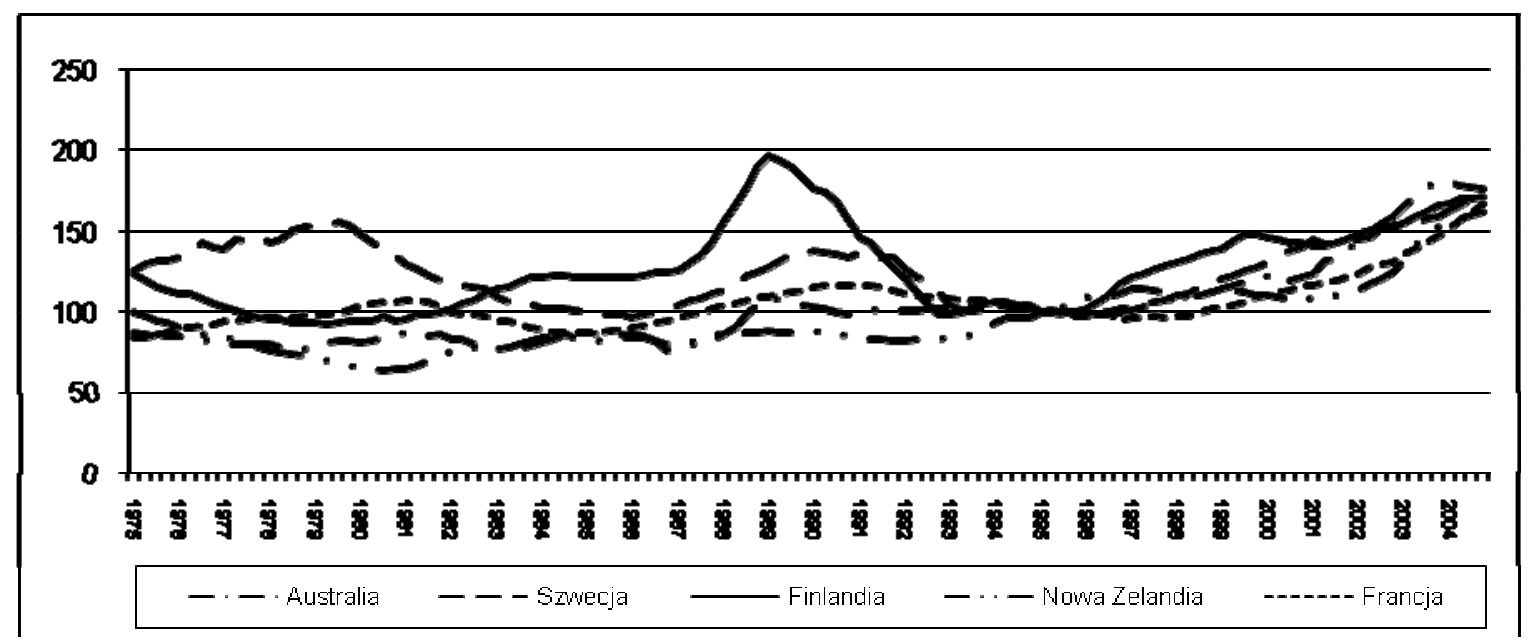

Graph 2. Real house price indexes in Australia, Sweden, Finland, New Zealand and France in 1975-2004 ( I Q. $1995=100$ )

Source: as graph 1. 


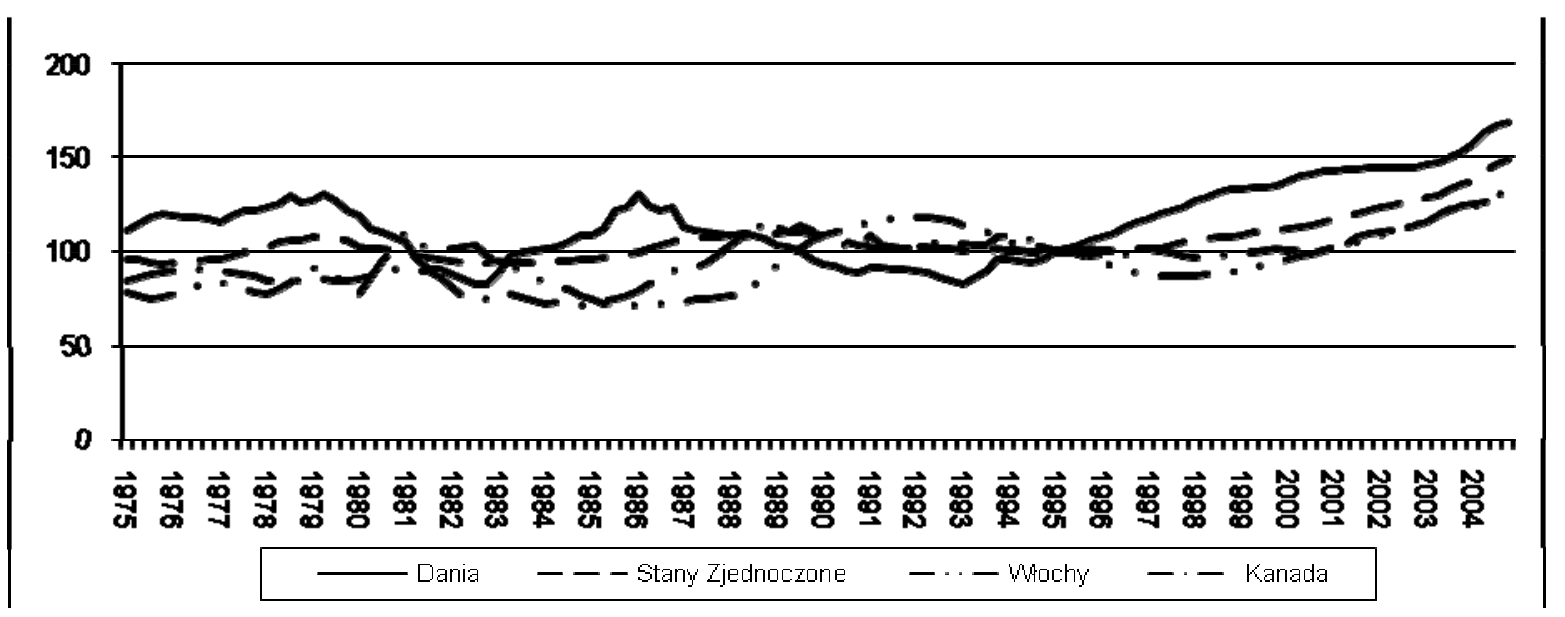

Graph 3. Real house price indexes in in Denmark, Canada, USA and Italy in 1975-2004 (I Q. $1995=100)$

Source: as graph 1.

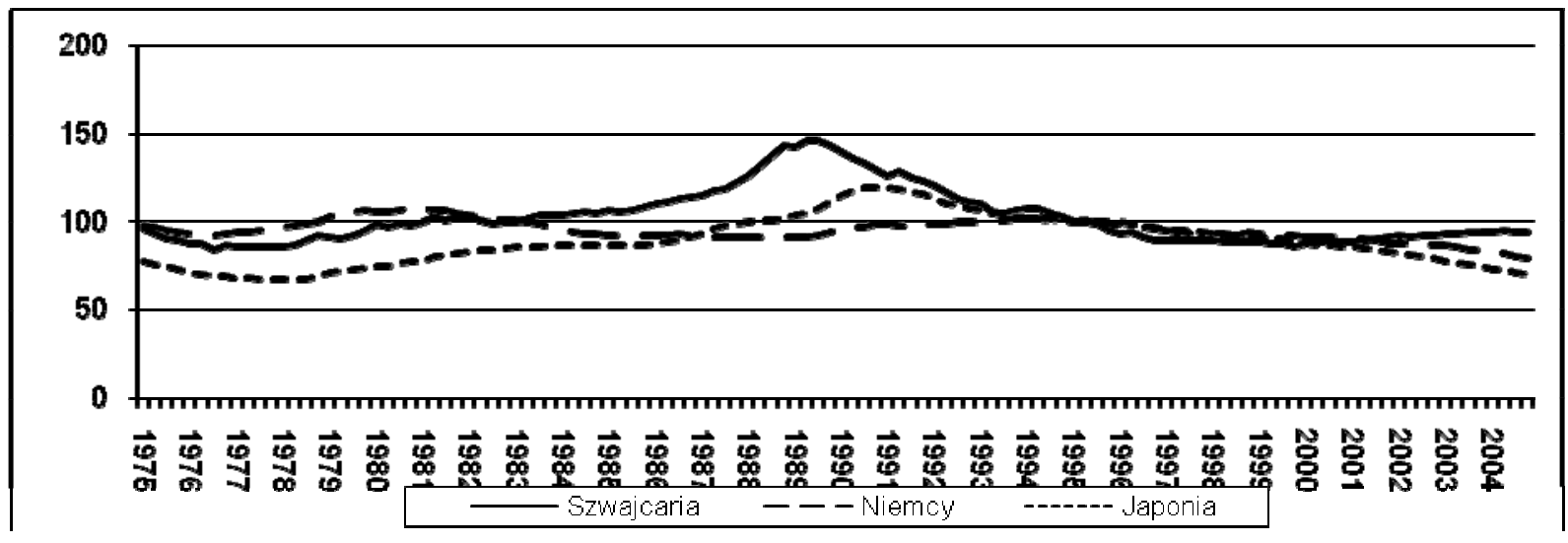

Graph 4. Real house price indexes inJapan, Germany and Switzerland in 1975-2004 (I Q. $1995=100)$

Source: as graph 1.

The highest, more than 200 per cent increase of real house prices, took place in Ireland. In Great Britain, Spain, the Netherlands and Norway prices increased less dynamic; they grew, however, more than 100 per cent. Australia, Sweden, Finland, New Zealand and France belong to the second group of countries in which real property prices increased more than 60 per cent in 1995-2005. In Denmark, USA, Italy and Canada real property prices increased around 60 per cent. The fourth group build countries in which real property prices decreased in 1995-2005. This tendency took place on real estate market of Switzerland, Germany and Japan.

Although the presented indexes of real property prices have been constructed basing on various data and various methods that could have an influence to accuracy of drawn conclusions, N. Girouard and others identified price cycles on real estate market in analysed countries in 1902004. According to their approach to the subject, single cycle consists of an increasing phase (positive price growth) and a decreasing phase (negative price growth). To avoid false cycles they assumed that minimum length of each phase has to be more than six quarters. Tables 1 and 2 present characteristics of increasing and decreasing phases of property prices' cycles in analysed countries in 1970-2004. 
Table 1. Characteristics of increasing phases of real house prices' cycles in chosen OECD countries in 1970-2004

\begin{tabular}{|c|c|c|c|c|c|c|}
\hline Country & $\begin{array}{c}\text { Number } \\
\text { of phases }\end{array}$ & $\begin{array}{c}\text { Average time } \\
\text { (in quarters) }\end{array}$ & $\begin{array}{c}\text { Average } \\
\text { price change } \\
\text { (in \%) }\end{array}$ & $\begin{array}{c}\text { Max. time (in } \\
\text { quarters) }\end{array}$ & $\begin{array}{c}\text { Max. price } \\
\text { change (in \%) }\end{array}$ & $\begin{array}{c}\text { Number of } \\
\text { phases of } \\
\text { change } \\
>\mathbf{1 5 \%}\end{array}$ \\
\hline USA & 3 & 17 & 15,3 & 23 & 17 & 1 \\
\hline Japan & 2 & 34,5 & 67 & 54 & 77,6 & 2 \\
\hline Germany & 3 & 21,3 & 12,1 & 27 & 15,7 & 1 \\
\hline France & 2 & 35,5 & 32,1 & 44 & 33 & 2 \\
\hline Italy & 2 & 34,5 & 81,9 & 44 & 98 & 2 \\
\hline Great Britain & 3 & 18,3 & 64,2 & 30 & 99,6 & 3 \\
\hline Australia & 6 & 14,3 & 31,6 & 32 & 84,7 & 3 \\
\hline Denmark & 2 & 25 & 44,3 & 37 & 56,6 & 2 \\
\hline Finland & 3 & 25,7 & 61,9 & 40 & 111,8 & 3 \\
\hline Ireland & 2 & 29 & 40,8 & 46 & 53,9 & 2 \\
\hline The Netherlands & 1 & 33 & 98,4 & 33 & 98,4 & 1 \\
\hline Norway & 2 & 14 & 33,7 & 16 & 56,3 & 1 \\
\hline Spain & 3 & 15 & 63,6 & 23 & 134,8 & 3 \\
\hline Sweden & 2 & 19 & 35,8 & 22 & 42,5 & 2 \\
\hline Switzerland & 3 & 28,3 & 40,2 & 53 & 73,5 & 2 \\
\hline Average & $\mathbf{2 , 7}$ & $\mathbf{2 2 , 7}$ & $\mathbf{4 5 , 6}$ & $\mathbf{3 2 , 7}$ & $\mathbf{6 7 , 6}$ & $\mathbf{2 , 1}$ \\
\hline
\end{tabular}

Source: N. Girouard, M. Kennedy, P. van den Noord, Ch. André, Recent House Price Developments: The Role of Fundamentals, Economics Department Working Papers No. 475, 2006, p. 7.

Table 2. Characteristics of increasing phases of real house prices' cycles in chosen OECD countries in 1970-2004

\begin{tabular}{|c|c|c|c|c|c|c|}
\hline Country & $\begin{array}{c}\text { Number } \\
\text { of phases }\end{array}$ & Average time & $\begin{array}{c}\text { Average } \\
\text { (in quarters) }\end{array}$ & $\begin{array}{c}\text { Max. time } \\
\text { (in \%) }\end{array}$ & $\begin{array}{c}\text { Max. price } \\
\text { change } \\
\text { (in \%) }\end{array}$ & $\begin{array}{c}\text { Number of } \\
\text { phases of } \\
\text { change } \\
>\mathbf{1 5 \%}\end{array}$ \\
\hline USA & 3 & 14,3 & $-9,9$ & 21 & $-13,9$ & 0 \\
\hline Japan & 1 & 15 & $-30,5$ & 15 & $-30,5$ & 1 \\
\hline Germany & 2 & 16,5 & $-10,7$ & 25 & $-15,3$ & 1 \\
\hline France & 2 & 18,5 & -18 & 23 & $-18,1$ & 2 \\
\hline Italy & 2 & 22 & $-30,6$ & 23 & $-35,3$ & 2 \\
\hline Great Britain & 3 & 16,3 & -25 & 25 & $-33,7$ & 2 \\
\hline Australia & 5 & 10 & $-10,1$ & 19 & $-14,7$ & 0 \\
\hline Denmark & 2 & 21,5 & $-36,2$ & 29 & $-36,8$ & 2 \\
\hline Finland & 3 & 14 & $-28,4$ & 19 & $-49,7$ & 2 \\
\hline Ireland & 2 & 16 & $-15,5$ & 23 & $-27,1$ & 1 \\
\hline The Netherlands & 1 & 29 & $-50,4$ & 29 & $-50,4$ & 1 \\
\hline Norway & 3 & 21,3 & $-19,8$ & 28 & $-40,6$ & 1 \\
\hline Spain & 3 & 19,3 & $-21,6$ & 31 & $-32,2$ & 2 \\
\hline Sweden & 3 & 22,3 & $-22,7$ & 26 & $-37,9$ & 2 \\
\hline Switzerland & 2 & 26,5 & $-34,8$ & 41 & $-40,7$ & 2 \\
\hline Average & $\mathbf{2 , 6}$ & $\mathbf{1 8 , 5}$ & $-\mathbf{2 3 , 3}$ & $\mathbf{2 5 , 4}$ & $-\mathbf{3 2 , 4}$ & $\mathbf{1 , 3}$ \\
\hline
\end{tabular}

Source: as Table 1.

The Table 1 and 2 shows that an average length of price cycle on real estate market in this particular period of time was around ten years. In the course of increasing phase (around 
six years approximately), real property prices increased by ca. 45 per cent. Decreasing phase was relatively shorter (around five years approximately) and real property prices decreased by ca. 25 per cent. To work on the assumption that significant increase or decrease of real prices is 15 per cent minimum, phases of sudden increases and decreases of prices can be determined. It seems to be interesting that in all analysed countries it was at least one period in which real property prices increased by more than 15 per cent, but significant price decrease had not taken place in every country in thirty-year period (USA and Australia).

Analysis of fluctuations of property prices in various countries shows that these cycles vary not only with duration of time but also with fluctuation's amplitude. The heart of the matter lies mainly with economic and demographic factors, as well as with the structure of real estate market specific for every country.

Main reason why the interest in real estate market constantly increases is a significant price growth (real price growth) in the beginning of 21 st century. Moreover, in this period of time property prices started to behave differently in relation to GDP. In OECD countries in 1970-2000 changes of property prices aimed to the GDP changes, but after 2000 this trend has been changed and prices became anti-cyclic.

\section{Data used in the research and the methodology of isolating the cyclical fluctuations of dwelling prices in selected cities in Poland}

Dwelling prices indexes per square metre were constructed with a median method. The data on asking prices used to construct dwelling price indexes were collected. As a result of methodological processes (repeated sales offers were omitted - this phenomenon of repeated offers was caused by reporting them to more than one agency.). The number of collected offers satisfies the condition of representative sample. In the chart 6 real dwelling prices indexes in selected cities in Poland in the years 1996-2011 are presented.

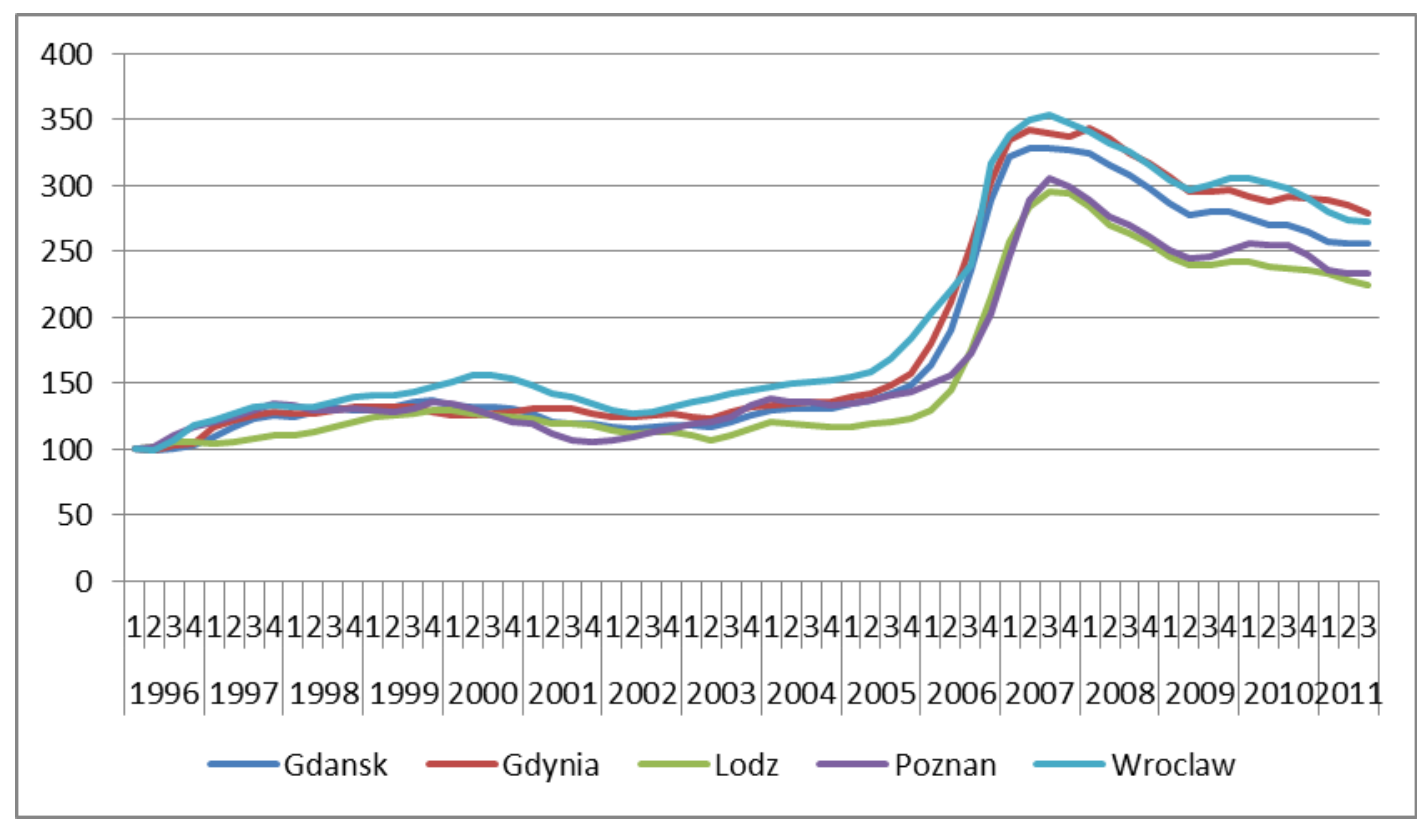

Graph 1. Real dwelling price indexes in selected cities inPoland in the years 1996-2011 Source: own research based on the data of WYCENTER.PL

The analysis of graph 1 shows that realdwelling price indexes in case of: Gdansk increased by $156 \%$, Gdynia increased by $178 \%$, Lodz increased by $124 \%$, Poznan increased 
by $133 \%$, Wroclaw increased by 172\%during the years 1996-2011 (in case of nominal terms these growths were much higher). Particulary rapid growth took place in the year 2006. The rapid growth resulted from many factors. Firstly, the market was informed about the possibility of increasing V.A.T. (value added tax) by $22 \%$. Thus only those flats that were built just at that moment were burdened with $7 \%$ V.A.T. Secondly, the other important information was that the year 2006 was the last year to use tax relief. Taking into consideration the above mentioned facts it seems that rapid growth of demand met fixed supply and resulted in huge flat price growth in the year 2006. Thirdly, there was a big mortgage affordability at that time in Poland. Fourthly, polish economy was in good condition. Moreover, there was speculative capital doing business on the market and behavior of many buyers was irrational.

\section{Fluctuations of dwelling price in selected cities in Poland}

Dwelling price indexes mentioned above were the basis for further analyses. The aim was to determine morphologic attributes of these fluctuations. It was assumed in the analysis that the upper (lower) turning point appears in the period when the value of the analyzed indicator reaches its maximum (minimum). After establishing the turning points it was possible to differentiate the phases of the business cycles. Therefore, each cycle consists of an increase phase (between the lower and upper turning point) and a decrease phase (between the upper and lower turning point).Restrictions were imposed to ensure that the periods of increases and decreases had a minimum length of six quarters in order to avoid spurious cycles. Table 2 presents morphologic of cyclical fluctuations of prices of 1 sq.m of flat attributes in selected cities in Poland in 1996-III 2011.

Table 2.Morphologic of cyclical fluctuations of prices of $1 \mathrm{~m}^{2}$ of flat in selected cities in Poland in 1996-2011

\begin{tabular}{|c|c|c|c|c|c|}
\hline \multirow{3}{*}{ City } & \multirow{3}{*}{$\begin{array}{l}\text { Attributes of } \\
\text { cycle }\end{array}$} & \multicolumn{4}{|c|}{ Phases of cyclical fluctuations } \\
\hline & & increasing & decreasing & increasing & decreasing \\
\hline & & \multicolumn{4}{|c|}{ Within the time } \\
\hline \multirow{4}{*}{ Gdansk } & Time & up to IVQ 1999 & IQ 2000-II 2002 & IIIQ 2002 - IIQ 2007 & IIIQ 2007 \\
\hline & \multicolumn{5}{|c|}{ Length in quarters } \\
\hline & phases & $\min 16$ & 10 & 20 & 17 \\
\hline & cycle & $\min 16$ & & 30 & $\min 17$ \\
\hline \multirow{4}{*}{ Gdynia } & Time & up to IQ 1999 & IIQ 1999-IIQ 2003 & IIIQ 2003 - IIQ 2007 & IIIQ 2007 \\
\hline & \multicolumn{5}{|c|}{ Length in quarters } \\
\hline & phases & $\min 13$ & 17 & 16 & 17 \\
\hline & cycle & $\min 13$ & & 33 & $\min 17$ \\
\hline \multirow{4}{*}{ Lodz } & Time & up to IVQ 1999 & IQ 2000-IIQ 2003 & IIIQ 2003 - IIIQ 2007 & IVQ 2007 \\
\hline & \multicolumn{5}{|c|}{ Length in quarters } \\
\hline & phases & $\min .16$ & 14 & 17 & 16 \\
\hline & cycle & $\min .16$ & & 31 & $\min 16$ \\
\hline \multirow{4}{*}{ Poznan } & Time & up to IVQ 1999 & IQ 2000-IVQ 2001 & IIQ 2003 - IIIQ 2007 & IVQ 2007 \\
\hline & \multicolumn{5}{|c|}{ Length in quarters } \\
\hline & phases & $\min .16$ & 8 & 23 & 16 \\
\hline & cycle & $\min .16$ & & 31 & $\min 16$ \\
\hline
\end{tabular}




\begin{tabular}{|c|c|c|c|c|c|}
\multirow{4}{*}{ Wroclaw } & Time & up to IIIQ 2000 & IVQ 2000-IIQ 2002 & IIIQ 2002 - IIIQ 2007 & IVQ 2007 \\
\cline { 2 - 6 } & \multicolumn{5}{|c|}{ Length in quarters } \\
\cline { 2 - 6 } & phases & min. 19 & 7 & 21 & 16 \\
\cline { 2 - 6 } & cycle & min. 19 & \multicolumn{2}{|c|}{28} & min 16 \\
\hline
\end{tabular}

Source: Based on own calculations.

In 1996 - III q 2011 on the secondary housing market in selected cities in Poland it was possible to observe two increasing and two decreasing phase. The beginning of the first increasing phase cannot be specified because cyclical fluctuations of prices of 1 sq.m of flat before 1996 are unknown and the bottom turning point was not found. It can only be assumed, however, that increasing phase lasted at average about16. The length of the cycle of dwelling prices that took place around 2003-2007 was about 30 quarters. In the 2007 next decreasing phase begun in all examined cities.

\section{Conclusion}

The main aim of the paper was to identify changes on the secondary housing market in the years in selected cities in Poland. In 1996 - 2011 one full cycle has been identified; it lasted quite 8 years. To compare the length of this cycle to price cycles in OECD countries, it was close to an average period. It has to be stated that decreasing phases on real estate market took place in the period of economic slump in Poland. This is identical to other researches. They show that dwelling's price cycle responds to key economic elements but it is not a simple reflection of the business cycle of the country.

\section{Summary}

The market of separate goods, as well as the whole economy, is subject to economic fluctuations. All markets fluctuate, including the real estate market. The problem of price cycles on residential market has been attempted in this paper.The subject scope of the research includes price fluctuations on the secondary housing market, involving both property rights and cooperative property rights for private accommodation. In this research only dwellings located in multifamily buildings are analyzed.

\section{References}

Baum, A. (2001), Evidence of Cycles In European Commercial Real Estate Markets - and Some Hypoteses, w S. Brown, C. Liu, A Global Perspective on Real Estate Cycles, Massachusetts: Kluwer.

Dehesh, A., Pugh, C. (1997), Real Estate Cycle, Internationalised Transmission Mechanism and the Japanese Bubble Economy, RICS Research Paper Series 1997, vol. 2, No. 6.

Gawron, H. (2006), Opłacalność inwestowania na rynku nieruchomości, Wyd. AE w Poznaniu, Poznań.

Girouard, N., Kennedy, M., P. van den Noord, Ch. André (2006), Recent House Price Developments: The Role of Fundamentals, Economics Department Working Papers 2006, No. 475.

Key, T., Macgregor, B., Nanthakumaran, N., Zarkesh, F. (1994), Understanding the Property Cycle, RICS, London. 
Kucharska-Stasiak, E. (2006), Nieruchomość w gospodarce rynkowej, Wyd. Naukowe PWN, Warszawa.

Rottke, N., Wernecke, M., Schwartz, A. (2003), Real Estate Cycles in Germany - Causes, Empirical Analysis and Recommendations for the Management Decisions, Journal of Real Estate Literature 2003, vol. 11, No. 3.

Trojanek, R. (2008), Wahania cen na rynku mieszkaniowym, Wyd. AE w Poznaniu, Poznań. 